\title{
Protecting the protectors: indemnification agreements for REB members
}

\section{Leah E. Hutt}

$\mathrm{L}$ iability risk is a serious issue for members of research ethics boards (REBs) at public institutes in Canada. Yet, few Canadian institutes indemnify their REB members. Some simply have not considered the issue; others have deliberated and decided to not indemnify. This paper addresses arguments that might be marshalled against indemnification for REB members: that they do not face a real liability risk; that the institute's insurance policy offers sufficient protection; that to do so would increase costs; and that precedent is lacking. Each of these arguments is specious. I encourage REB members to engage with their institutes about the issue and challenge such refusals.

Lawsuits against REB members were once only a theoretical risk. Recently, however, this risk has materialized in the United States; for example, Robertson et al v. McGee et al 2001 (available: www.sskrplaw.com/gene/robertson /complaint-new.html), Guckin v. Nagle et al 2002 (www .sskrplaw.com/gene/guckin.html) and Wadev. Oregon Health and Science University, 2002 (www.sskrplaw.com/gene/cordy .html). In Canada, a hospital was held liable for its REB's actions (Weiss v. Solomon, I989; 48 CCLT 28o, Quebec Supreme Court), and the Medical Research Council of Canada (the predecessor to the Canadian Institutes of Health Research) warned of actions against REB members themselves. ${ }^{1}$

Although the creativity of counsel for plaintiffs forms the only limit to the types of claims that might be made against REB members, negligence constitutes the most likely basis. Some of the most obvious ways in which a negligence allegation could be framed against an REB or its members include

... failing to ensure informed consent standards were adequately met; failing to ensure proper screening of subjects; negligently approving unethical study designs; procedural negligence; and finally, failing to disclose conflicts of interest. ${ }^{2}$

Although no court has yet found an REB member liable, this should provide little comfort: most cases settle before going to trial, or have yet to be addressed by a court. The elements of a successful negligence action could certainly be made out, in the right situation. The US trend toward suing individual REB members is likely to spill into Canada, given research's international nature and Canada's proven tendency to follow the American jurisprudential lead (e.g., in class action litigation for injuries arising from use of prescription drugs such as Vioxx).

Canadian institutes themselves have recognized the risk of liability for REB members. Some institutes include the REB and its members in the indemnification agreements they sign with research sponsors. The existence of litigation, analyses by legal academics and governance bodies, and the inclusion of REBs and their members in institute-sponsor indemnification agreements are all evidence of a credible liability risk for Canadian REB members.

Generally, REB members are "insureds" under their institute's insurance policy — but institutes typically obtain coverage of only \$5-10 million per claim. This amount is inadequate, given the potential for very serious harm associated with some research trials. In cases of severely injured children, for example, courts have awarded damages or approved settlement agreements that exceed \$ro million (e.g., Renaerts v. Korn, I998: CanLII 4979, BC Supreme Court; and Sandhu v. Wellington Place Apartments, 2006: CanLII 20539, Ontario Superior Court of Justice). In addition to the damage award, legal costs and disbursements apply, which would be considerable for several reasons: the length of time cases take to get to trial; the potential complexity of the issues; and the possible requirement for independent legal counsel for each defendant relying on the institute's policy, since their interests may diverge. Against this backdrop, coverage having a policy limit of \$10 million is, at best, marginal.

\section{Between the institute and the REB member, it is the institute who should bear} the financial risks.

An institute secure in its view that its insurance coverage is sufficient should have no concerns offering indemnification to its REB members. An example agreement is available online (at www.cmaj.ca/cgi/content/full/175/Io/1229/DC1) as an Appendix.

At least 1 province has enacted legislation that seeks to protect volunteers serving nonprofit organizations. This sort of legislation may not, however, capture the circumstances of all REB members. Nova Scotia's Volunteer Protection Act (2002, c. I4, Statutes of Nova Scotia), for instance, defines a volunteer as a person performing services who is not compensated more than $\$ 500$ per year. This definition excludes those many REB members serving on hospital or university committees as a mandatory employment requirement. It also seems to exclude those whose service capacity is ambiguous, and could itself become the subject of legal debate within an action for harms arising from a research trial. An example of this could include an REB's legal representative for whom community service 
is an expectation of employment. Given that volunteerprotection legislation may not apply to all REB members and is not available in all provinces, reliance on legislation to protect such members is clearly insufficient.

Some might argue that indemnification increases an institutes' costs. Axiomatically, this can be true only if institutes admit to inadequate insurance coverage and therefore must pay the shortfall of a damage award, or if they increase coverage and pay the corresponding premium increase. Either way, increased cost is not a valid argument against indemnification; institutes should ensure adequate insurance is in place. Between the institute and the REB member, it is the institute who should bear the financial risks.

Perhaps the most disturbing reason offered for not signing indemnification agreements with REB members is that other institutes do not sign them. Surely, the mere fact that others have failed to do the right thing does not excuse one's own failure. Regardless, it is factually incorrect to say institutes do not indemnify their REB members: Canada's National Research Council, Trinity Western University in British Columbia and Izaak Walton Killam Health Centre in Nova Scotia indemnify their members. In addition to these Canadian examples, an Institute of Medicine report ${ }^{3}$ confirms that it is "common practice among larger [US] research universities" to indemnify members of ethics review boards. The report states that

... organizations should indemnify both internal and external board members to prevent them from being unduly influenced by the personal risks of potential litigation.... ${ }^{3}$

The issue is simple: There is a risk of liability. Protection currently provided by insurance and legislation is inadequate. It is not ethically defensible for public institutes to ask individual REB members to bear the risk themselves - particularly since they give their service for the institute's benefit.

The solution is likewise simple: Institutes should indemnify REB members. Although REB members may be held to account (through litigation or other means) for their actions, so long as they execute their duties in good faith they ought not to face financial ruin. The stakes in research are high for all involved; the financial protection of REB members should be no lower.

\section{This article has been peer reviewed.}

Leah E. Hutt is with the Dalhousie Health Law Institute, Halifax, NS.

Competing interests: None declared.

Acknowledgements: Many thanks to Jocelyn Downie for her generous input and thoughtful feedback. All errors remain those of the author.

\section{REFERENCES}

1. Medical Research Council of Canada. Report of the Working Group on Liability. Ottawa: The Council; I99o? (undated). p. 32 of 48.

2. Gold J. Watching the watchdogs: negligence, liability, and research ethics boards. Health Law J 2003;II:153-76.

3. Committee on Assessing the System for Protecting Human Research Participants, Institute of Medicine of the National Academies. Improving Human Research Participant Protection Program performance and clarifying roles. Chapter 6 in: Federman DD, Hanna KE, Rodriguez LL, editors. Responsible research: a systems approach to protecting research participants. Washington: The National Academies Press; 2002. p. I62-I96. Available: http://darwin.nap.edu/books/030908488I/html /I95.html (accessed 2006 Sept I5).

Correspondence to: Leah Hutt, Dalhousie Health Law Institute, 6061 University Ave., Halifax NS $\mathrm{B}_{3} \mathrm{H}_{4} \mathrm{Hg}$; fax 902 494-6879; huttle@gov.ns.ca

\section{CMA Careers}

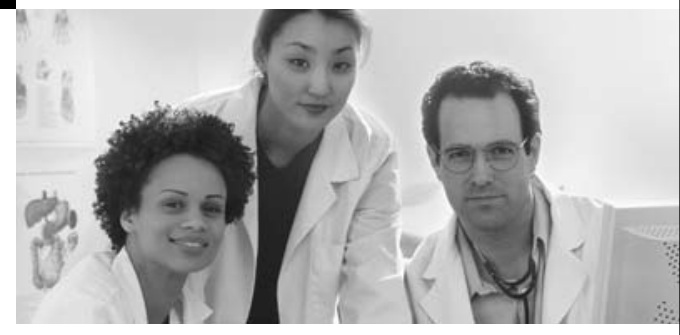

\section{Quality health care needs... a strong team!}

In today's highly competitive and changing health care market, an organization's success is built on the strength of its medical staff. The right mix of physicians to meet marketplace demands is crucial to success. Quality health care recruitment is made easy with CMA Careers.

Find your team... visit careers at ema.ca today!

$$
\begin{array}{r}
\text { ASSOCIATION } \\
\text { MÉDICALE } \\
\text { CANADIENNE }
\end{array}
$$

